\title{
Analysis of Genetic Diversity and Population Structure for the Native Tree Viburnum rufidulum Occurring in Kentucky and Tennessee
}

\author{
Deborah Dean ${ }^{1}$, Phillip A. Wadl ${ }^{1}$, and Denita Hadziabdic ${ }^{1}$ \\ Department of Entomology and Plant Pathology, University of Tennessee, 2505 EJ Chapman Drive, \\ Knoxville, TN 37996 \\ William E. Klingeman \\ Department of Plant Sciences, University of Tennessee, 2431 Joe Johnson Drive, Knoxville, TN 37996
}

Bonnie H. Ownley

Department of Entomology and Plant Pathology, University of Tennessee, 2505 EJ Chapman Drive, Knoxville, TN 37996

Timothy A. Rinehart

U.S. Department of Agriculture, Agricultural Research Service, Southern Horticultural Laboratory, 810 Highway 26 West, Poplarville, MS 39470

\begin{abstract}
Adam J. Dattilo
Biological Compliance, TN Valley Authority, West Tower11B-K, 400 West Summit Hill Drive, Knoxville, TN 37902

Brian Scheffler

U.S. Department of Agriculture, Agricultural Research Service, 141 Experiment Station Road, Stoneville, MS 38776
\end{abstract}

\author{
Robert N. Trigiano ${ }^{2}$ \\ Department of Entomology and Plant Pathology, University of Tennessee, 2505 EJ Chapman Drive, \\ Knoxville, TN 37996
}

\begin{abstract}
AdDitional INDEX words. admixture, adoxaceae, genetic diversity, microsatellites, population genetics
AвSTRACT. Viburnum rufidulum is a deciduous tree native to North America that has four-season appeal, which provides commercial horticultural value. In addition, the plant has unique and attractive red pubescence on leaf buds and petioles, common to no other Viburnum species. As habitat undergoes development and subsequent fragmentation of native plant populations, it is important to have baseline genetic information for this species. Little is known about the genetic diversity within populations of $V$. rufidulum. In this study, seven microsatellite loci were used to measure genetic diversity, population structure, and gene flow of $235 \mathrm{~V}$. rufidulum trees collected from 17 locations in Kentucky and Tennessee. The genotype data were used to infer population genetic structure using the program InStruct and to construct an unweighted pair group method with arithmetic mean dendrogram. A single population was indicated by the program InStruct and the dendrogram clustered the locations into two groups; however, little bootstrap support was evident. Observed and expected heterozygosity were 0.49 and 0.78 , respectively. Low-to-moderate genetic differentiation $\left(F_{\mathrm{ST}}=0.06\right)$ with evidence of gene flow $\left(\mathrm{N}_{\mathrm{m}}=4.82\right)$ was observed among 17 populations of $V$. rufidulum. A significant level of genetic diversity was evident among $V$. rufidulum populations with most of the genetic variations among individual trees $(86.37 \%)$ rather than among populations (13.63\%), and a Mantel test revealed significant correlation between genetic and geographical distance $(r=0.091, P=0.001)$. The microsatellites developed herein provide an initial assessment or a baseline of genetic diversity for $V$. rufidulum in a limited area of the southeastern region of the United States. The markers are a genetic resource and can be of assistance in breeding programs, germplasm assessment, and future studies of $V$. rufidulum populations, as this is the first study to provide genetic diversity data for this native species.
\end{abstract}

Viburnum rufidulum is a member of Adoxaceae, which includes the genera Viburnum, Sambucus, Sinadoxa, and Adoxa. The genus Viburnum is estimated to include $\approx 170$

Received for publication 5 May 2015. Accepted for publication 14 Aug. 2015. We thank USDA (grant number 58-6404-1-637) and University of Tennessee Institute of Agriculture, AgResearch for financial and facilities support of this project. We also express our gratitude to the reviewers and editors for comments and suggestions.

${ }^{1}$ These authors contributed equally to this work.

${ }^{2}$ Corresponding author. E-mail: rtrigian@utk.edu. species with worldwide distribution (Winkworth and Donoghue, 2004). Viburnum rufidulum, one of the 12 species native to North America (U.S. Department of Agriculture, 2008), is a small deciduous tree capable of growing to a height of about 3.0 to $9.0 \mathrm{~m}$ (Dirr, 2007). Cymes of small white flowers attract a variety of pollinators in late spring (Miliczky and Osgood, 1979), which facilitate outcrossing of this self-incompatible species and attractive drupes are produced in late summer that begin as pale green and mature to almost black-purple in late 
fall. The species can be easily identified by the red pubescence that occurs on leaf buds, petioles, and abaxial surfaces of leaves. This abundant pubescence gives $V$. rufidulum its common name of rusty blackhaw, and the attractive and unique rust-colored pubescence distinguishes it from all other Viburnum species (Dirr, 1998). The native range of $V$. rufidulum extends from the southeastern United States, spreading north into the southern portions of Illinois, Indiana, Missouri, and Ohio, and extending westward to eastern sections of Kansas, Oklahoma, and Texas. Viburnum rufidulum is often found growing as an understory tree on limestone outcroppings in shallow, xeric environments (Homoya, 1987).

The genus Viburnum has many species that are economically important to ornamental horticulture (Clement and Donoghue, 2012; Dean et al., 2011). Many nonnative Viburnum species and cultivars are popular; however, the anthropogenic introduction of nonnative species is a major threat (second only to habitat loss) to the biodiversity of native plants (Gurevitch and Padilla, 2004; Vitousek and Walker, 1989). In addition, urbanization has led to loss of habitat and fragmentation that divides contiguous populations into many smaller patches where they are at risk of genetic isolation (Fahrig, 2003; Lienert, 2004). Spatial isolation may promote inbreeding and the reduction of gene flow among populations (den Nijs and Oostermeijer, 1997). Moreover, genetic differentiation, gene flow, and levels of heterozygosity of native plant populations are of interest to biologists and serve as indicators of local genetic diversity of species in plant and animal communities (Kati et al., 2004; Lindenmayer et al., 1999).

Viburnum rufidulum has not been genetically characterized and there is a dearth of information concerning population structure and genetic diversity. Molecular studies can provide valuable insight into the genetic composition of populations and this knowledge can assist in planning long-range management of at-risk habitat. This type of study is often the first step taken to manage and conserve native populations. Moreover, genetic characterization of native North American species can become important to successful conservation efforts, should such actions be required (Hamrick and Godt, 1996; Holsinger and Gottlieb, 1991; Newton et al., 1999).

Microsatellites, also referred to as SSR (SSRs), are a class of codominant markers that are useful in assessing genetic diversity of plants due to their high level of polymorphism (Gupta et al., 1996). These markers are often used for population genetic studies that involve closely related individuals and are a valuable tool for studying gene flow, inbreeding, and levels of differentiation between populations (Arnold et al., 2002; Hadziabdic et al., 2012; Zhang and Hewitt, 2003).

In this study, the native North American species $V$. rufidulum was genetically characterized. To our knowledge, this is the first study to examine the genetic diversity and population structure of $V$. rufidulum in Kentucky and Tennessee. Therefore, this study affords a baseline of genetic diversity and population structure for this species. The specific objectives of this study were to develop and use microsatellite markers to: 1) quantify genetic diversity, 2) analyze population structure of various indigenous populations of $V$. rufidulum, and 3) generate necessary data to serve as a genetic resource for breeding programs, germplasm assessment, and future studies.

\section{Methods and Materials}

Plant material and collection. During late winter and early spring of 2011 through 2013, 235 samples of $V$. rufidulum leaves and flower buds were collected from trees at 17 sampling areas located in Kentucky (KY) and Tennessee (TN). There were three sites in Fayette County (KY), six sites in Knox County (TN), six in Loudon County (TN), and two sites in Anderson County (TN) (Table 1). The sample sizes from the various sites ranged from 2 to 33 trees. We elected to include small populations in the study as each of those collection sites was undergoing significant environmental disturbances from urbanization or had invasive species present. In addition, small population sizes did not affect estimates of gene diversity in prior studies (Nybom and Bartish, 2000; Semaan and Dodd, 2008). Individual samples were labeled and global positioning system (GPS) coordinates recorded (Table 1).

Table 1. Collection site, population code, sample size and GPS coordinates for 235 Viburnum rufidulum trees collected in Kentucky (KY) and Tennessee (TN).

\begin{tabular}{|c|c|c|c|c|}
\hline Collection site & Population code (population no.) & Sample size & Latitude $\left({ }^{\circ} \mathrm{N}\right)$ & Longitude $\left({ }^{\circ} \mathrm{W}\right)$ \\
\hline Anderson County, TN & WC1-Worthington Cemetery (1) & 33 & 36.0289 & 84.1222 \\
\hline Anderson County, TN & WC2 - Worthington Cemetery (2) & 24 & 36.0288 & 84.1242 \\
\hline Knox County, TN & WEB_-Webb School (3) & 29 & 35.9232 & 84.1170 \\
\hline Knox County, TN & $\mathrm{CP}-$ Cowan Park (5) & 14 & 35.8515 & 84.0932 \\
\hline Knox County, TN & FR1-Forks of the River (6) & 7 & 35.9591 & 83.8211 \\
\hline Knox County, TN & FR2-Forks of the River (7) & 3 & 35.9593 & 83.8209 \\
\hline Loudon County, TN & TL1-Tellico Lake (9) & 12 & 35.7682 & 84.2579 \\
\hline Loudon County, TN & TL2-Tellico Lake (10) & 6 & 35.7650 & 84.2647 \\
\hline Loudon County, TN & TL3-Tellico Lake (11) & 6 & 35.7670 & 84.2583 \\
\hline Loudon County, TN & TL4-Tellico Lake (12) & 15 & 35.7687 & 84.2607 \\
\hline Loudon County, TN & TL5-Tellico Lake (13) & 20 & 35.7668 & 84.2552 \\
\hline Loudon County, TN & TL6-Tellico Lake (14) & 6 & 35.7670 & 84.2593 \\
\hline
\end{tabular}


Table 2. Characteristics of Viburnum rufidulum microsatellite loci that were used to genotype 235 trees collected in Kentucky and Tennessee.

\begin{tabular}{|c|c|c|c|c|}
\hline Locus & GenBank accession no & Primer sequence $\left(5^{\prime}-3^{\prime}\right)$ & Repeat motif & Observed size range (bp) \\
\hline VR004 & $\mathrm{KC} 236414$ & $\begin{array}{l}\text { F:CTACCGCACATATGCACCTAC } \\
\text { R:TACAGATCGGGAAGGTGTAAGG }\end{array}$ & $(\mathrm{TG})_{6} \ldots(\mathrm{TG})_{7}$ & $210-223$ \\
\hline VR005 & KC236415 & $\begin{array}{l}\text { F:TGCTTCCATCTCTTTTCTCTCC } \\
\text { R:GTGTGTGGCTGTGTTTGTACG }\end{array}$ & $(\mathrm{TG})_{12} \ldots(\mathrm{TG})_{6}$ & $113-182$ \\
\hline VR008 & $\mathrm{KC} 236416$ & $\begin{array}{l}\mathrm{F}: C C A A G C C C C A T T T T A T A A A T A C C \\
\text { R:CATTCTGCCATTTTATTGAGTCC }\end{array}$ & $(\mathrm{GT})_{15}$ & $93-123$ \\
\hline VR011 & KC236417 & $\begin{array}{l}\text { F:GCATATGTGCACACACGAGAG } \\
\text { R:TATGGATTGGGAAGGTGTTAGG }\end{array}$ & $(\mathrm{CA})_{14}$ & $162-245$ \\
\hline VR012 & KC236418 & $\begin{array}{l}\text { F:CAAAGTGGGCAGAGAAGTAGC } \\
\text { R:CATTGTAGAGCACCACAAATTCC }\end{array}$ & $(\mathrm{TA})_{7}$ & $216-247$ \\
\hline VR028 & KC236419 & $\begin{array}{l}\text { F:GCTCGTAGCAGGGGTGTGTAT } \\
\text { R:CACGCACACTGCACACACT }\end{array}$ & $(\mathrm{CA})_{5} \ldots(\mathrm{AC})_{8}$ & $116-185$ \\
\hline VR043 & KC236420 & $\begin{array}{l}\text { F:TATGTGAGGATGAAGGTGATGG } \\
\text { R:TTACATTCTGGCAGTAGCAACC }\end{array}$ & $(\mathrm{CT})_{6} \ldots(\mathrm{TC})_{5} \ldots(\mathrm{TC})_{5}$ & $213-276$ \\
\hline
\end{tabular}

Plant materials were transported from the field to laboratory on ice and then stored at $-80{ }^{\circ} \mathrm{C}$ until DNA isolation.

DNA EXTRACTION, DEVELOPMENT OF MICROSATELLITES, AND POLYMERASE CHAIN REACTION AMPLIFICATION. Genomic DNA was extracted from unexpanded leaves or closed floral buds with the DNeasy ${ }^{\circledR}$ Plant Mini Kit (Qiagen, Valencia, CA). DNA purity was evaluated and quantified with a spectrophotometer (NanoDrop ND-1000; NanoDrop Technologies, Wilmington, DE). A small insert genomic DNA library $(V$. rufidulum accession no. 24 collected in Anderson County, $\mathrm{TN})$ was constructed and enriched for $(\mathrm{CA})_{\mathrm{n}}$ motif microsatellites using the methods of Dean et al. (2011), Wadl et al. (2011), and Wang et al. (2007). Colonies with putative microsatellites were sequenced using $\mathrm{T} 3$ and $\mathrm{T} 7$ primers on a capillary electrophoresis DNA sequencer (ABI 3730XL; Applied Biosystems, Foster City, CA). After sequencing, microsatellite repeats were identified using Imperfect SSR Finder (Stieneke and Eujayl, 2007) and vector flanking regions were trimmed from the insert using the program VecScreen (National Center for Biotechnology Information, 2013). Forty-seven primer pairs were designed using Primer 3.0 (Untergrasser et al., 2012) with the following optimum parameters: primer oligonucleotide length $=20 \mathrm{bp}, \mathrm{GC}$ percent $=50 \%$, and an annealing temperature of greater than $56{ }^{\circ} \mathrm{C}$. Primer pairs were synthesized by Integrated DNA Technologies (Coralville, IA). Primer pairs were optimized for polymerase chain reaction (PCR) using genomic DNA from $20 \mathrm{~V}$. rufidulum samples and a $10-\mu \mathrm{L}$ amplification reaction consisted of the following: $4 \mathrm{ng}$ of genomic DNA, $0.25 \mu \mathrm{M}$ forward and reverse primers, $2.0 \mathrm{mM} \mathrm{MgCl}_{2}, 0.2 \mathrm{mM}$ dNTPs, $1 \times$ PCR Gold Buffer (Lifescience Technologies, Carlsbad, CA), 0.4 U AmpliTaq Gold DNA polymerase (Lifescience Technologies), and 5\% dimethyl sulfoxide. Thermal cycler conditions were as follows: one cycle of $94{ }^{\circ} \mathrm{C}$ for $3 \mathrm{~min}$, and 35 cycles of $94{ }^{\circ} \mathrm{C}$ for $40 \mathrm{~s}, 58^{\circ} \mathrm{C}$ for $40 \mathrm{~s}, 72{ }^{\circ} \mathrm{C}$ for $30 \mathrm{~s}$, and one cycle of $72{ }^{\circ} \mathrm{C}$ for $4 \mathrm{~min}$. Amplicons were sized on a capillary electrophoresis system (QIAxcel, Qiagen). Of the 47 primer pairs, seven microsatellite markers that amplified DNA from most samples and exhibited polymorphic alleles were optimized and used to amplify DNA from the $235 \mathrm{~V}$. rufidulum trees collected in KY and TN (Table 2). Reactions that failed to produce amplified products were repeated twice before an individual was considered null at that locus.
Table 3. Genetic diversity estimates for 235 Viburnum rufidulum trees genotyped at seven loci and averaged over all populations as calculated by FSTAT version 2.9.3 (Goudet, 2001) and GenAlEx version 6.4.1 (Peakall and Smouse, 2006).

\begin{tabular}{lcccrrrrr}
\hline Locus $^{\mathrm{z}}$ & $\mathrm{N}_{\mathrm{a}}^{\mathrm{y}}$ & $H_{\mathrm{o}}$ & $H_{\mathrm{e}}$ & \multicolumn{1}{c}{$A_{\mathrm{R}}$} & \multicolumn{1}{c}{$F_{\mathrm{IS}}$} & \multicolumn{1}{c}{$F_{\mathrm{IT}}$} & $F_{\mathrm{ST}}$ & $\mathrm{N}_{\mathrm{m}}$ \\
\hline VR004 & 35 & 0.88 & 0.87 & 18.48 & -0.02 & 0.03 & 0.05 & 4.69 \\
VR005 & 22 & 0.14 & 0.86 & 13.66 & 0.84 & 0.84 & 0.04 & 5.46 \\
VR008 & 8 & 0.98 & 0.76 & 6.23 & -0.30 & -0.26 & 0.04 & 6.68 \\
VR011 & 19 & 0.36 & 0.67 & 10.06 & 0.45 & 0.51 & 0.11 & 2.11 \\
VR012 & 14 & 0.70 & 0.76 & 8.79 & 0.08 & 0.11 & 0.04 & 6.52 \\
VR028 & 14 & 0.19 & 0.65 & 7.06 & 0.70 & 0.73 & 0.09 & 2.46 \\
VR043 & 20 & 0.16 & 0.87 & 13.64 & 0.81 & 0.82 & 0.04 & 5.83 \\
Mean & 18.80 & 0.49 & 0.78 & 11.13 & 0.36 & 0.40 & 0.06 & 4.82
\end{tabular}

${ }^{\mathrm{z}}$ All loci deviated from Hardy-Weinberg equilibrium $(P<0.001)$.

${ }^{y}$ Number of alleles $\left(\mathrm{N}_{\mathrm{a}}\right)$, observed heterozygosity $\left(H_{\mathrm{o}}\right)$, expected heterozygosity $\left(H_{\mathrm{e}}\right)$, allelic richness $\left(A_{\mathrm{R}}\right)$, inbreeding coefficient $\left(F_{\text {IS }}\right)$, overall breeding coefficient $\left(F_{\text {IT }}\right)$, genetic differentiation coefficient $\left(F_{S T}\right)$, gene flow $\left(\mathrm{N}_{\mathrm{m}}\right)$.

DAta AnAlysis. Before analyses, the data from the raw allele-length bp sizes were placed into allelic-size classes using the automated binning program FlexiBinV2 (Amos et al., 2007). The capillary electrophoresis system was used for PCR analyses and a conservative $2 \mathrm{bp}$ binned allele size determination error rate was used to permit reproducibility of data. To determine genetic diversity of $V$. rufidulum, 235 trees from Fayette County (KY) and Anderson, Knox, and Loudon counties (TN) were evaluated. Expected and observed heterozygosity $\left(\mathrm{H}_{\mathrm{e}}\right.$ and $\left.\mathrm{H}_{\mathrm{o}}\right)$, and the number of alleles $\left(\mathrm{N}_{\mathrm{a}}\right)$ for each polymorphic microsatellite locus across all collection sites were calculated using FSTAT version 2.9.2.3 (Goudet, 1995, 2001). The same program was used to calculate allelic richness $\left(A_{\mathrm{R}}\right)$, using a minimum sample size of 54 individuals [the smallest number of samples based on grouping of sites by county (Fayette County, KY)] or 108 alleles. Genetic differentiation or fixation index $\left(F_{\mathrm{ST}}\right)$, inbreeding $\left(F_{\mathrm{IS}}\right)$, overall inbreeding coefficients $\left(F_{\mathrm{IT}}\right)$, and gene flow $\left(\mathrm{N}_{\mathrm{m}}\right)$ were calculated with a 95\% confidence level using the program GenAlEx version 6.4.1 (Peakall and Smouse, 2006). Principal coordinate analysis (PCoA) was completed to visualize structure in the relationships among $V$. rufidulum collection sites using a covariance matrix with data standardization. This multivariate 
analysis identifies major patterns among a multivariate data set and creates two-dimensional scatter plots by using the first and third principal coordinates. All loci were tested for deviation from Hardy-Weinberg equilibrium [HWE $(P<0.001)]$ in FSTAT using a modified Markov chain method described by Guo and Thomson (1992) with 9999 permutations.

Genetic structure of $V$. rufidulum populations was examined using two Bayesian clustering programs, InStruct (Gao et al., 2007) and Structure version 2.3.4 (Pritchard et al., 2000). Program InStruct eliminates HWE assumptions within clusters and is recommended for populations where inbreeding is occurring or with a partially selfing species (Gao et al., 2007). The following parameters were used in the program InStruct: 10 Markov chain Monte Carlo (MCMC) chains for each value of $K$, iterations of $1,000,000$ a burn-in period of 500,000 with a thinning interval of 20 iterations, followed by the admixture mode. For estimation of number of subpopulations, we used the deviance information criterion [DIC (Gao et al., 2011)]. Structure version 2.3.4, which is widely used for inferring the number of populations $(K)$ in population genetic studies, was used to compare with InStruct analysis. The program Structure group individuals based on their multilocus genotypes with an assumption that HWE or linkage disequilibria are the result of population structure, and therefore it attempts to identify those populations that are not in disequilibrium (Pritchard and Donnelly, 2001). However, Gilbert et al. (2012) reported that the program Structure was unable to reproduce the value of $K$ in $30 \%$ of the analyses preformed. To maximize reproducibility of Structure results (Gilbert et al., 2012), we used 20 iterations/ independent runs for each value of $K(K=1$ to 10$)$ with a burn-in period of 250,000 , and 250,000 MCMC replications after burn-in. The admixture (mixed ancestry among individuals that may be present) and the correlated allele frequencies (allele frequencies may be similar among the populations) models were also employed. The most probable value of $K$ was selected based on the calculation of $[P(\mathrm{X} \mid \mathrm{K})]$ (probability distribution), and by estimating the number of populations with the ad hoc statistic $\Delta K$ (Evanno et al., 2005) using Structure Harvester version

(B)
0.6.1 (Earl and von Holdt, 2012). Although, $\Delta K$ helps in identifying the correct number of genetic clusters in many data sets, it should not be used when $K=1$, which is the artifact of Evanno's methodology (Evanno et al., 2005).

Analysis of molecular variance (AMOVA) was performed using Arlequin version 3.5.1.2 (Excoffier and Lischer, 2010) to determine the hierarchical distribution of genetic variation of individuals within and among populations. The following three AMOVA analyses were performed: 1) all $V$. rufidulum individuals were placed into one hierarchical group from the 17
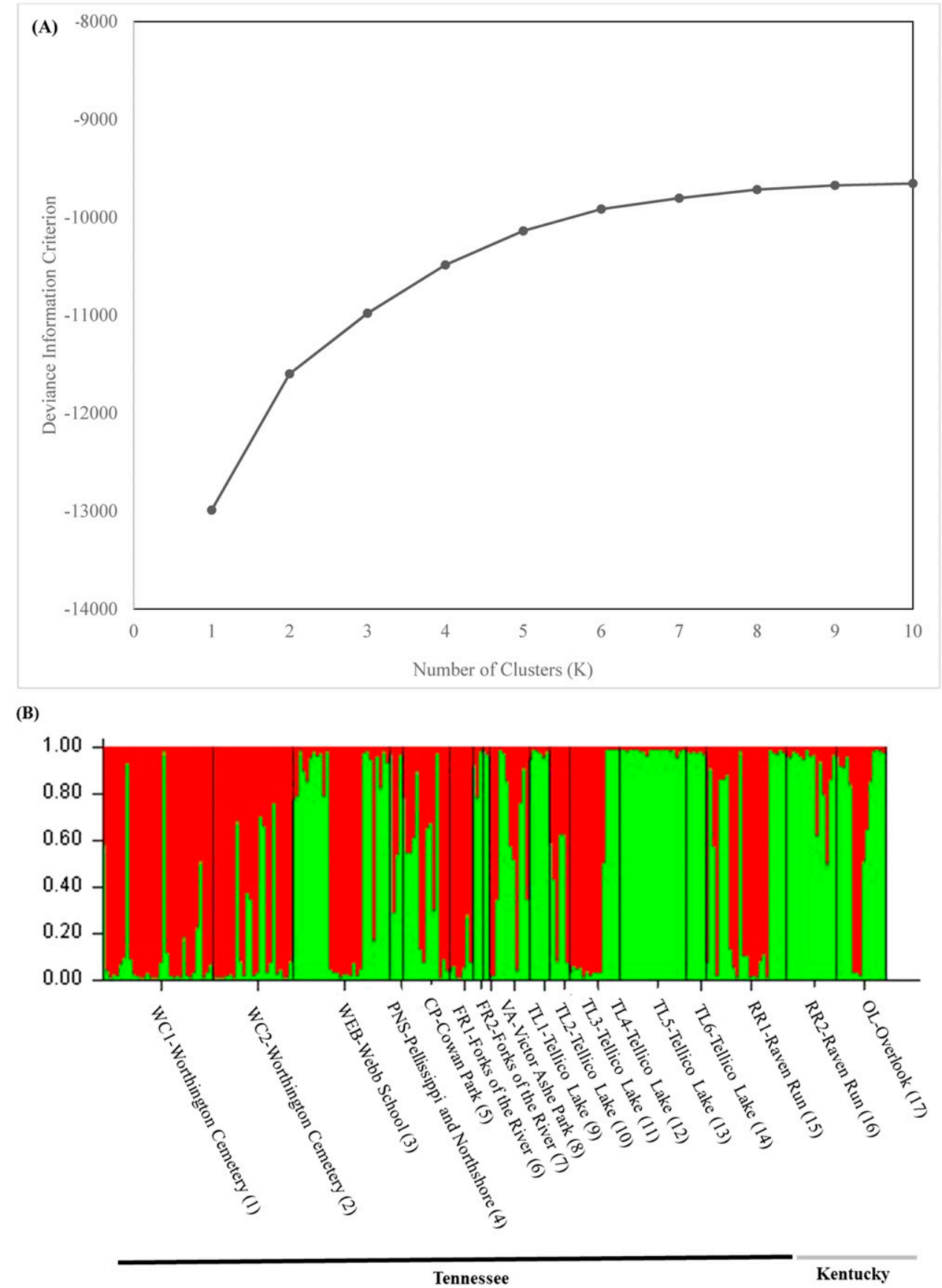

Fig. 1. Bayesian assignment probabilities for 235 individuals of Viburnum rufidulum from 17 populations using programs InStruct [A (Gao et al., 2007)] and Structure 2.3.4 [B (Pritchard et al., 2000)]. InStruct indicated presence of one $(K=1)$ genetic cluster using deviance information criterion calculations $(\mathbf{A})$. Structure indicated two genetic clusters $(K=2)$ - the proportion of red or green in each bar indicates the assignment probabilities of $V$. rufidulum individuals to each of the two clusters $(\mathbf{B})$. 
collection sites, 2) V. rufidulum individuals were grouped geographically based on county location, and 3) the state in which samples were collected (Table 1). The summary statistic was used to quantify genetic differentiation and the hierarchical partitions between, among, and within groups or populations (Excoffier, 2007; Holsinger and Weir, 2009; Kronholm et al., 2010). The program Arlequin was used to estimate genetic differentiation between 17 populations of $V$. rufidulum using pairwise $F_{\mathrm{ST}}$ calculations with 10,000 permutations $(P<0.05)$.

The correlation between genetic and geographic distance was analyzed with the Mantel test for isolation by distance with 10,000 permutations (Mantel, 1967) using GenAlEx version 6.4.1 (Peakall and Smouse, 2006). An unweighted pair group method with arithmetic mean (UPGMA) dendrogram was created using standard genetic distance (Nei, 1972) among $17 \mathrm{~V}$. rufidulum populations. In addition, a bootstrap analysis was performed with the program Populations 1.2.32 (Langella, 2002) and branch support values were estimated using 500 bootstrap randomizations. A consensus tree with bootstrap support values was generated and viewed using TreeView version 1.6.6 (Page, 1996).

\section{Results}

Seven polymorphic microsatellite markers amplified 8 to 35 alleles/locus or 132 alleles. Locus VR008 had the fewest alleles (8) and VR004 revealed the most alleles (35). Without the assumption of random mating within the samples, all markers deviated from Hardy-Weinberg equilibrium $[P<0.001$ (Table $3)$ ]. The mean values for inbreeding and overall inbreeding coefficient were $F_{\text {IS }}=0.36$ and $F_{\text {IT }}=0.40$, which supported the finding of an overall heterozygote deficiency. The allelic richness $\left(A_{\mathrm{R}}\right)$ across four county localities (corrected by rarefaction of minimum sample size of 52 individuals) had a mean of 11.13, ranging from 6.23 (VR008) to 18.48 (VR004) (Table 3$)$. The greatest degree of gene diversity was found in Anderson County, TN $\left(H_{\mathrm{e}}=0.84\right)$ and at locus VR004 $\left(H_{\mathrm{e}}=\right.$ $0.87)$, whereas the least was in Knox County, TN $\left(H_{\mathrm{e}}=0.71\right)$ and locus VR028 $\left(H_{\mathrm{e}}=0.65\right)$ (Table 3$)$. Our results indicated low-to-moderate genetic differentiation across all loci $\left(F_{\mathrm{ST}}=\right.$ $0.06)$ with high levels of gene flow $\left(\mathrm{N}_{\mathrm{m}}=4.82\right)$ (Table 3).

The Bayesian clustering analysis using InStruct indicated that the highest value of $K$ occurred at $K=$ 1 (Fig. 1A). However, Structure analysis indicated that the highest value of $\Delta K$ occurred at $K=2$. According to Structure, two genetic clusters emerged with subpopulations PNS, FR2, TL1, TL2, TL4, and OL being admixed almost evenly (Fig. 1B), whereas the remaining collections were more uniform in genetic composition. However, the limitation of Evanno's ad hoc statistic $\Delta K$ (2005) is that it fails to identify $\Delta K=1$, but was retained here for overall comparison and educational purposes when using similar data sets. Results from InStruct were also in agreement with the PCoA scatter plot (Fig. 2). The first three principal coordinates from the genetic distance matrix explained $32.09 \%, 50.02 \%$, and $65.37 \%$ of variation across large, noncontiguous (fragmented), single population, respectively.

Significant genetic differentiation exists among populations of $V$. rufidulum (Table 4). When all 17 sample locations were grouped into one hierarchical group, AMOVA analysis revealed that the greatest amount of genetic variation was found among individuals $(86.37 \%)$, rather than between $V$. rufidulum populations (13.63\%), indicating moderate-to-high genetic differentiation $\left(F_{\mathrm{ST}}=0.13, P<0.001\right)$ (Table 4$)$. When $V$. rufidulum populations were grouped based on geographical grouping (county and state), results revealed a similar pattern of individual variation rather than differences among (59.91\%) and within populations $(60.40 \%)$ of individual variation for four counties and two states. However, genetic differentiation was low-to-moderate when four counties were compared $\left(F_{\mathrm{ST}}=\right.$ $0.06, P<0.001)$ and very low when two states (TN and KY) were compared $\left(F_{\mathrm{ST}}=0.01, P<0.001\right)$ (Table 4$)$. The $F_{\text {IS }}$ and $F_{\text {IT }}$ values indicated a deficit of heterozygotes due to nonrandom breeding at the population level.

Considering all $17 \mathrm{~V}$. rufidulum collection sites, the greatest differentiation occurred between sites FR1 (population 6) and VA (population 8) in Knox County, TN $(0.46, P<0.05)$. Populations PNS (population 4) and RR2 (population 16) from Knox and Fayette counties had the smallest genetic differentiation (0.03, $P<0.05)$ (Table 5). The UPGMA analysis (Fig. 3) clustered the 17 collections into two major clades, but the relationships were not supported by bootstrap values. Analysis of isolation by distance across all $V$. rufidulum individuals showed a positive significant correlation between genetic and geographical distance $[r=0.091, P=0.001$ (Fig. 4)].

\section{Discussion}

Moderate levels of genetic diversity exist within the $17 \mathrm{~V}$. rufidulum collection sites in KY and TN. Furthermore, our study indicated moderate genetic differentiation between the

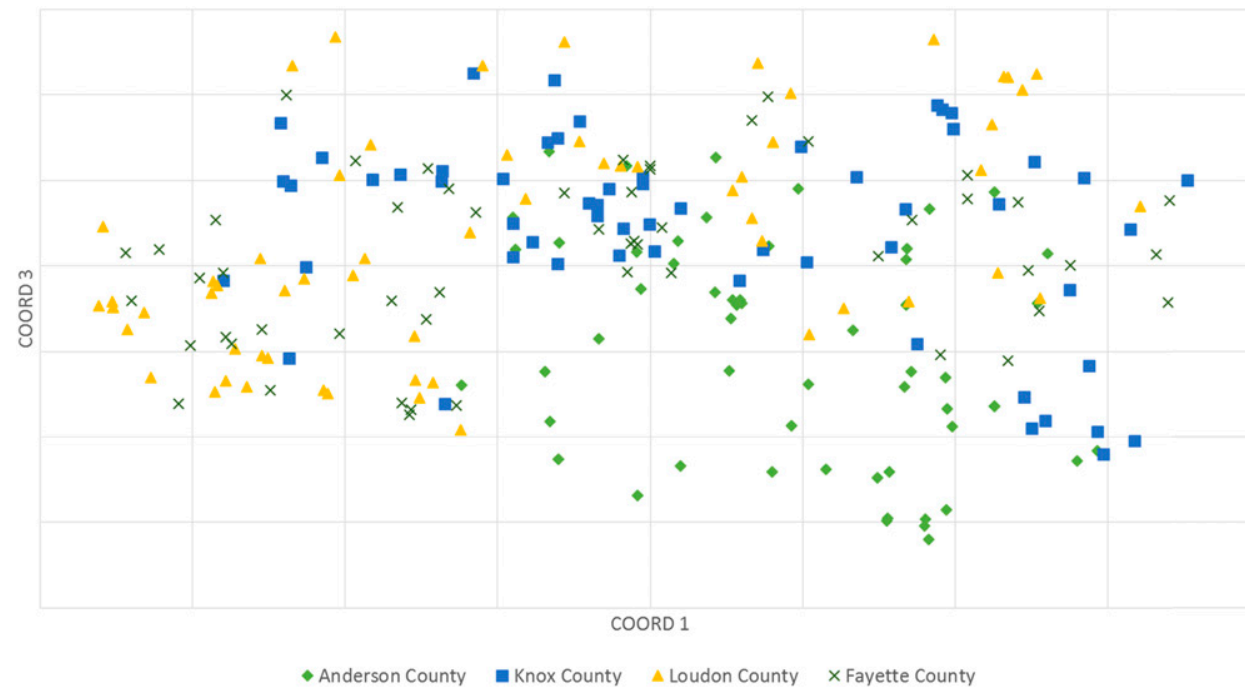

Fig. 2. Principal coordinate analysis of Viburnum rufidulum sampling localities from Kentucky (Fayette County) and Tennessee (Anderson County, Knox County, and Loudon County). Analysis revealed a single, large, noncontiguous (fragmented) population, which was supported by InStruct analysis $[K=1$ (Gao et al., 2007)]. 
Table 4. Analysis of molecular variance for Viburnum rufidulum populations occurring in Kentucky and Tennessee based on seven microsatellite markers using ARLEQUIN version 3.5.1.2 (Excoffier and Lischer, 2010).

\begin{tabular}{|c|c|c|c|c|c|c|}
\hline Source of variation & $\overline{\mathrm{df}}$ & Sum of squares & Variance component & Percent variation & Fixation indices $^{\mathrm{z}}$ & $P$ value \\
\hline \multicolumn{7}{|l|}{ Among 17 populations of $V$. rufidulum } \\
\hline Within populations & 453 & $1,104.16$ & $2.44 \mathrm{Vb}$ & 86.37 & $F_{\mathrm{ST}}=0.13$ & 0.0001 \\
\hline \multicolumn{7}{|l|}{ Among four different counties } \\
\hline Among populations & 3 & 75.07 & $0.18 \mathrm{Va}$ & 6.43 & $F_{\text {IS }}=0.36$ & 0.0001 \\
\hline Among individuals within populations & 231 & 834.02 & $0.96 \mathrm{Vb}$ & 33.66 & $F_{\mathrm{IT}}=0.40$ & 0.0001 \\
\hline \multicolumn{7}{|l|}{ Among Kentucky and Tennessee populations } \\
\hline Among populations & 1 & 9.53 & $0.03 \mathrm{Va}$ & 1.21 & $F_{\mathrm{IS}}=0.39$ & 0.0001 \\
\hline Among individuals within populations & 233 & 899.55 & $1.08 \mathrm{Vb}$ & 38.39 & $F_{\mathrm{IT}}=0.40$ & 0.0001 \\
\hline Among individuals & 235 & 399.50 & $1.70 \mathrm{Vc}$ & 60.40 & $F_{\mathrm{ST}}=0.01$ & 0.0001 \\
\hline Total & 469 & $1,308.59$ & 2.81 & & & \\
\hline
\end{tabular}

${ }^{\mathrm{z}} F_{\mathrm{IS}}=$ inbreeding coefficient of individuals compared with the population, $F_{\mathrm{IT}}=$ variance of the total population, $F_{\mathrm{ST}}=$ variance among subpopulations compared with the overall variance.

Table 5. Pairwise comparison of the variance among subpopulations compared with the overall variance $\left(F_{\mathrm{ST}}\right)$ pairwise comparison values of 17 populations of Viburnum rufidulum occurring in Kentucky and Tennessee as calculated by the program ARLEQUIN version 3.5.1.2 (Excoffier and Lischer, 2010).

\begin{tabular}{rccccccccccccccccc}
\hline & 1 & 2 & 3 & 4 & 5 & 6 & 7 & 8 & 9 & 10 & 11 & 12 & 13 & 14 & 15 & 16 & 17 \\
\hline 1 & & $*$ & $*$ & $*$ & $*$ & $*$ & $*$ & $*$ & $*$ & $*$ & $*$ & $*$ & $*$ & $*$ & $*$ & $*$ & $*$ \\
2 & 0.05 & & $*$ & $*$ & $*$ & $*$ & $*$ & $*$ & $*$ & $*$ & $*$ & $*$ & $*$ & $*$ & $*$ & $*$ & $*$ \\
3 & 0.17 & 0.13 & & $*$ & $*$ & $N S$ & $*$ & $*$ & $*$ & $*$ & $*$ & $*$ & $*$ & $*$ & $*$ & $*$ & $*$ \\
4 & 0.10 & 0.13 & 0.15 & & $*$ & $*$ & $*$ & $*$ & $*$ & $*$ & $*$ & $*$ & $*$ & $*$ & $*$ & $*$ & $*$ \\
5 & 0.14 & 0.22 & 0.24 & 0.16 & & NS & $*$ & $*$ & $*$ & $*$ & $*$ & $*$ & $*$ & $*$ & $*$ & NS & NS \\
6 & 0.20 & 0.22 & 0.22 & 0.25 & 0.23 & & $*$ & $*$ & NS & NS & $*$ & $*$ & NS & $*$ & $*$ & $*$ & $*$ \\
7 & 0.11 & 0.12 & 0.21 & 0.07 & 0.20 & 0.28 & & $*$ & $*$ & $*$ & $*$ & $*$ & $*$ & $*$ & $*$ & $*$ & $*$ \\
8 & 0.16 & 0.22 & 0.33 & 0.18 & 0.28 & 0.46 & 0.19 & & $*$ & $*$ & $*$ & $*$ & $*$ & $*$ & $*$ & $*$ & $*$ \\
9 & 0.19 & 0.18 & 0.11 & 0.15 & 0.14 & 0.15 & 0.16 & 0.33 & & $*$ & $*$ & $*$ & NS & $*$ & $*$ & $*$ & $*$ \\
10 & 0.20 & 0.20 & 0.19 & 0.21 & 0.16 & 0.05 & 0.23 & 0.37 & 0.09 & & $*$ & $*$ & $*$ & $*$ & $*$ & $*$ & $*$ \\
11 & 0.16 & 0.17 & 0.25 & 0.21 & 0.30 & 0.28 & 0.18 & 0.24 & 0.21 & 0.23 & & $*$ & $*$ & $*$ & $*$ & $*$ & $*$ \\
12 & 0.14 & 0.15 & 0.15 & 0.18 & 0.25 & 0.30 & 0.20 & 0.24 & 0.18 & 0.27 & 0.17 & & $*$ & $*$ & $*$ & $*$ & $*$ \\
13 & 0.13 & 0.12 & 0.09 & 0.11 & 0.13 & 0.11 & 0.14 & 0.27 & 0.02 & 0.07 & 0.17 & 0.13 & & NS & $*$ & $*$ & NS \\
14 & 0.09 & 0.09 & 0.11 & 0.12 & 0.20 & 0.19 & 0.15 & 0.18 & 0.12 & 0.18 & 0.09 & 0.09 & 0.05 & & $*$ & $*$ & $*$ \\
15 & 0.16 & 0.15 & 0.13 & 0.13 & 0.16 & 0.12 & 0.12 & 0.32 & 0.06 & 0.08 & 0.20 & 0.24 & 0.06 & 0.14 & & $*$ & $*$ \\
16 & 0.07 & 0.10 & 0.11 & 0.03 & 0.10 & 0.19 & 0.07 & 0.11 & 0.12 & 0.17 & 0.13 & 0.12 & 0.08 & 0.06 & 0.11 & & NS \\
17 & 0.08 & 0.09 & 0.10 & 0.04 & 0.08 & 0.15 & 0.07 & 0.19 & 0.08 & 0.11 & 0.18 & 0.15 & 0.04 & 0.09 & 0.07 & 0.03 &
\end{tabular}

Codes for collection sites and population numbers: Tennessee (populations 1-14)-WC1 = Worthington Cemetery (1), WC2 $=$ Worthington Cemetery (2), WEB = Webb School (3), PNS = Pellissippi and Northshore (4), CP = Cowan Park (5), FR1 = Forks of the River (6), FR2 = Forks of the River (7), VA = Victor Ashe Park (8), TL1 = Tellico Lake (9), TL2 = Tellico Lake (10), TL3 = Tellico Lake (11), TL4 = Tellico Lake (12), TL5 = Tellico Lake (13), TL6 = Tellico Lake (14); Kentucky (populations 14-17)—RR1 = Raven Run (15), RR2 = Raven Run (16), OL = Overlook (17).

Values below diagonal represent pairwise $F_{\text {ST }}$ values and above the diagonal is significance level $\left({ }^{*} P<0.05 ; \mathrm{NS}=\right.$ not significant $)$.

collection sites and significant isolation of the populations by distance.

The moderate levels of genetic diversity found at the 17 collection sites of $V$. rufidulum are similar to other studies involving the population genetics of outcrossing trees (Furches et al., 2013; Hamrick et al., 1992; Hamrick and Godt, 1996). The average gene diversity of outcrossing plant species in other studies employing microsatellite markers was 0.65 (Nybom, 2004). However, our study revealed an average gene diversity of 0.78 , which was higher than that reported for other studies of woody species (Hornero et al., 2001; Kikuchi and Isagi, 2002). High levels of diversity can be expected in plants that have outcrossing mating systems, are long lived, and have more than one generation that coincides simultaneously with other generations at the same location (Hamrick and Godt, 1996; Marra et al., 2013; Nybom, 2004; Till-Bottraud and Gaudeul, 2002). The high mean value of gene diversity within $V$. rufidulum populations could be related to the extensive geographic range of the species. Gene diversity contributes to the stability of populations when adverse conditions occur (such as disease and insect epidemics) and to successful adaptation and survival during environmental changes (Freeman and Herron, 1998; Leonard, 1969). The highest levels of diversity in our study were at sites that boasted large areas of unspoiled habitat, which included sites in Anderson and Loudon counties in TN and Fayette County, KY, whereas the least gene diversity was found at urban sites in Knox County, TN. Interestingly, while the vast area at the Forks of the Rivers sites (Knox County) is an ideal habitat for $V$. rufidulum, very few trees were growing there, and those that were discovered were in tight clusters. Furthermore, the trees growing at two sites at the Forks of the Rivers in Knox County (FR1 and FR2) lacked the vigor of the trees growing at the sites with higher gene diversity.

Structure is one of the most widely used population genetics programs (Gao et al., 2007), but calculates $\Delta K$ (number of subpopulations) in a manner (Evanno et al., 2005) in which the minimum value obtainable is $K=2$-a subpopulation finding of 


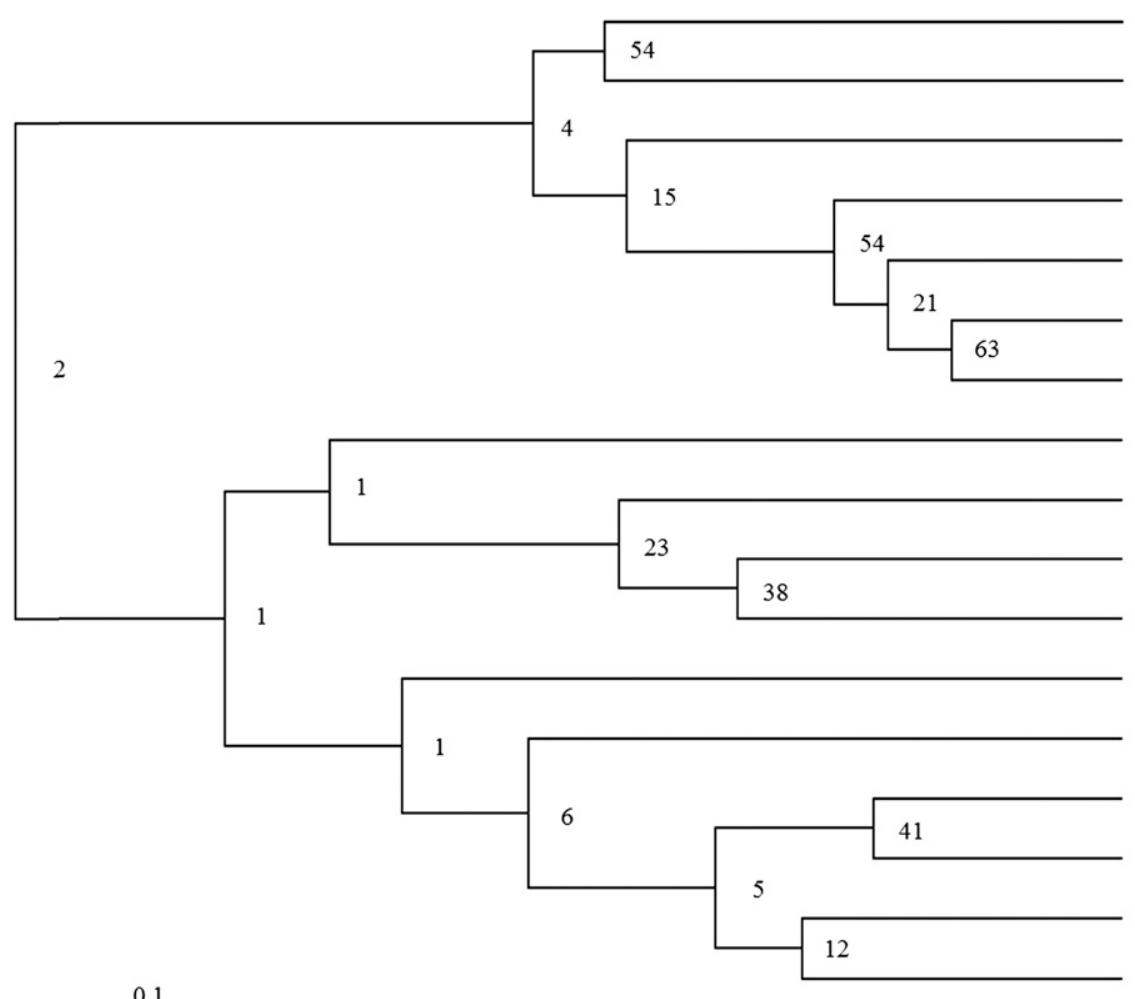

Fig. 3. An unweighted pair group method with arithmetic mean (UPGMA) dendrogram of the Viburnum rufidulum populations based on standard genetic distance (Nei, 1972) was generated from Populations 1.2.31 (Langella, 2002) and displayed in TreeView (Page, 1996). Five hundred bootstrap randomizations are reported as percentages at each node. The scale bar represents 0.1 substitutions per nucleotide site. Codes for collection sites and population numbers: Tennessee (populations 1-14) - WC1 $=$ Worthington Cemetery (1), WC2 $=$ Worthington Cemetery (2), WEB $=$ Webb School (3), PNS = Pellissippi and Northshore (4), CP = Cowan Park (5), FR1 = Forks of the River (6), FR2 = Forks of the River (7), VA = Victor Ashe Park (8), TL1 = Tellico Lake (9), TL2 = Tellico Lake (10), TL3 = Tellico Lake (11), TL4 = Tellico Lake (12), TL5 = Tellico Lake (13), TL6 = Tellico Lake (14); Kentucky (populations 14-17)—RR1 = Raven Run (15), RR2 = Raven Run (16), OL = Overlook (17).

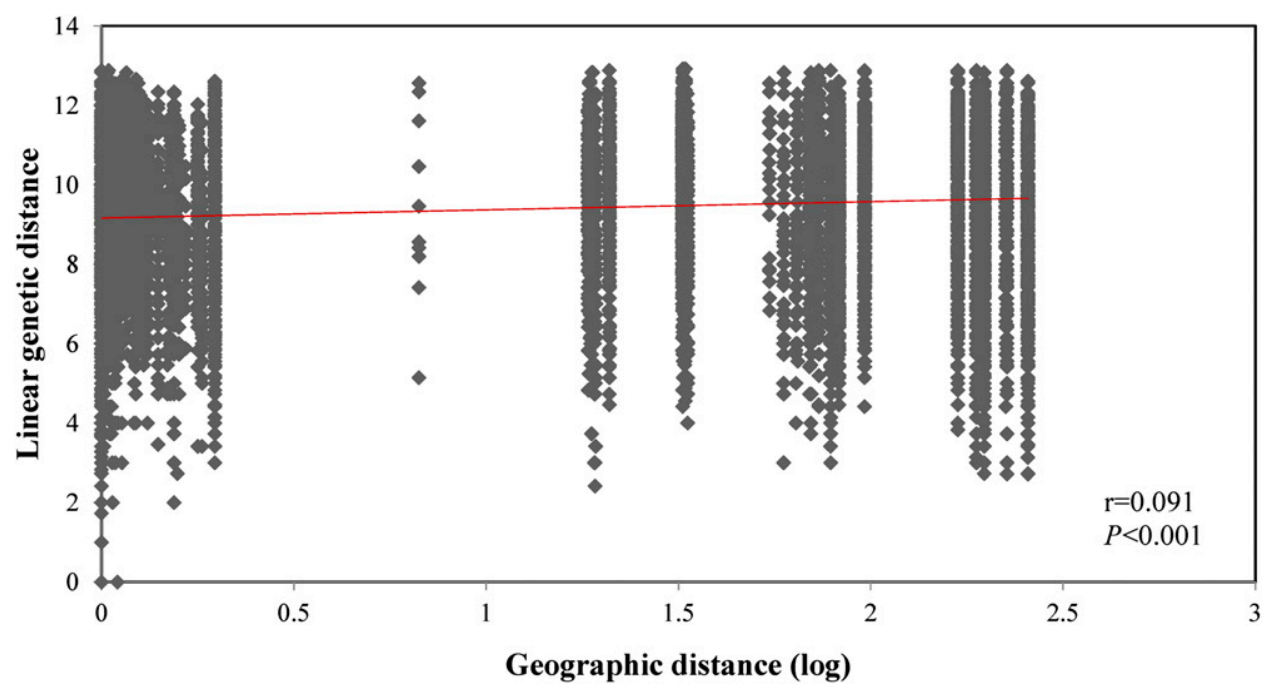

Fig. 4. Pairwise genetic distance and geographical distances of 235 Viburnum rufidulum samples collected from 17 populations in Kentucky and Tennessee displayed as a scatterplot. The probability value was obtained with the Mantel test after 9999 permutations using the program GenAlEx 6.4.1 (Peakall and Smouse, 2006). Geographic distance values are in log scale.

1 is mathematically impossible using this methodology. In our study, Structure analysis partitioned $V$. rufidulum individuals from the 17 collection sites into two principal genetic clusters; however, admixture of the two populations was noted within almost all of the collection areas. The presence of admixture within the two genetic clusters, as inferred by the program Structure, implied that interbreeding or sharing of alleles has occurred between the two populations. Most of the individuals from 17 collection sites displayed relatively equal membership assignment probability to one of the two genetic clusters identified by Structure with the exception of sampling areas $\mathrm{WC} 1, \mathrm{WC} 2$, and TL5 in which limited admixture was observed. However, population analysis using the program Structure is not adequate when genotypic data indicate nonrandom mating or mating among close relatives (Gao et al., 2007; Gilbert et al., 2012). The aforementioned authors argue that the program Structure should be modified when inferring population structure of inbreeding species or species not conforming to HWE proportions (Gao et al., 2007). Therefore, an analysis was performed with the program Instruct, which reduces the false-positive rates, corrects for bias toward spurious admixture, and allows identification of different mating systems in structured as well as unstructured populations (Gao et al., 2007). A finding of $K=1$ using DIC values from program InStruct indicated that the trees in this study are part of large, noncontiguous, single population with low-tomoderate genetic differentiation, and high gene flow. In contrast, the program Structure indicated two populations and that the population is fragmented. However, the $F_{\text {IS }}$ values indicate a high inbreeding coefficient and suggest the trees are in fact breeding with closely related individuals. Therefore, we conclude that from our study, the result of the Structure analysis, $K=2$ populations, is an artifact of the Evanno's ad hoc statistic $\Delta K$ (Evanno et al., 2005) and $V$. rufidulum subpopulations represent single genetic cluster across KY and TN. These findings also support the contention of Gao et al. (2007) and Gilbert et al. (2012) that the program Structure should not be used with inbreeding populations. As with other obligate outcrossing species, the overall heterozygote deficit and deviation from HWE proportions found in this study may be explained by the ability of this $V$. rufidulum to mate 
with half-sibs, resulting in inbreeding among closely related individuals (Ægisdóttir et al., 2009; Hadziabdic et al., 2012).

This study provides the first genetic assessment of $V$. rufidulum and makes available a foundation of genetic information for the species. However, because of the small scope of this study, it is not possible to ascertain if these results and observations can be extrapolated to the larger distribution of $V$. rufidulum and additional studies are warranted. In addition, future studies would benefit from using more microsatellite markers and include a much larger sampling area. Sampling from a larger area and greater number of locations within the natural range of $V$. rufidulum would provide a much more robust representation of genetic diversity and population structure of the species throughout its native range. This study provides the data and information necessary to serve as a genetic resource for breeding programs, germplasm assessment, assistance in maintenance of the natural genetic structure, and future biodiversity and genetic studies of this native species.

\section{Literature Cited}

Ægisdóttir, H.H., P. Kuss, and J. Stocklin. 2009. Isolated populations of a rare alpine plant show high genetic diversity and considerable population differentiation. Ann. Bot. (Lond.) 104:1313-1322.

Amos, W., J.I. Hoffmann, A. Frodsham, L. Zhang, S. Best, and A.V.S. Hill. 2007. Automated binning of microsatellite alleles: Problems and solutions. Mol. Ecol. Notes 7:10-14.

Arnold, C., M. Rossetto, J. McNally, and R.J. Henry. 2002. The application of SSRs characterized for grape (Vitis vinifera) to conservation studies in Vitaceae. Amer. J. Bot. 89:22-28.

Clement, W.L. and M.J. Donoghue. 2012. Barcoding success as a function of phylogenetic relatedness in Viburnum, a clade of woody angiosperms. Evol. Biol. 12:1-13.

Dean, D., P.A. Wadl, X. Wang, W.E. Klingeman, B.H. Ownley, T.A. Rinehart, B. Scheffler, and R.N. Trigiano. 2011. Screening and characterization of 11 novel microsatellite markers from Viburnum dilatatum. HortScience 46:1456-1459.

den Nijs, H.C.M. and J.G.B. Oostermeijer. 1997. Reproductive biology and gene flow in a fragmented landscape. Bocconea 7:153-165.

Dirr, M.A. 1998. Manual of woody landscape plants: Their identification, ornamental characteristics, culture, propagation and uses. 5 th ed. Stipes Publ., Champaign, IL.

Dirr, M.A. 2007. Viburnums: Flowering shrubs for every season. Timber Press, Portland, OR.

Earl, D.A. and B.M. von Holdt. 2012. STRUCTURE HARVESTER: A website and program for visualizing STRUCTURE output and implementing the Evanno method. Conserv. Genet. Resour. 4:359-361.

Evanno, G., S. Regnaut, and J. Goudet. 2005. Detecting the number of clusters of individuals using the software structure: A simulation study. Mol. Ecol. 14:2611-2620.

Excoffier, L. 2007. Analysis of population subdivision, p. 271-307. In: D.J. Balding, M. Bishop, and C. Cannings (eds.). Handbook of statistical genetics. 3rd ed. Wiley, Chichester, UK.

Excoffier, L. and H.E.L. Lischer. 2010. Arlequin suite ver. 3.5: A new series of programs to perform population genetics analyses under Linux and Windows. Mol. Ecol. Resour. 10:564-567.

Fahrig, L. 2003. Effects of habitat fragmentation on biodiversity. Annu. Rev. Ecol. Evol. Syst. 34:487-515.

Freeman, S. and J.C. Herron. 1998. Evolutionary analysis. PrenticeHall, Upper Saddle River, NJ.

Furches, M.S., R.L. Small, and A. Furches. 2013. Genetic diversity in three endangered pitcher plant species (Sarracenia; Sarraceniaceae) is lower than widespread congeners. Amer. J. Bot. 100:2092-2101.

Gao, H., K. Bryc, and C.D. Bustamante. 2011. On identifying the optimal number of population clusters via the deviance information criterion. PLoS One 6(6):e21014.
Gao, H., S. Williamson, and C.D. Bustamante. 2007. A Markov chain Monte Carlo approach for joint inference of population structure an inbreeding rates from multilocus genotype data. Genetics 176:16351651.

Gilbert, K.J., R.L. Andrew, D.G. Bock, M.T. Franklin, N.C. Kane, S. Moore, B. Moyers, S. Renaut, D.J. Rennison, T. Veen, and T.H. Vines. 2012. Recommendations for utilizing and reporting population genetic analyses: The reproducibility of genetic clustering using the program STRUCTURE. Mol. Ecol. 21:4925-4930.

Goudet, J. 1995. FSTAT (vers. 1.2): A computer program to calculate F-statistics. J. Hered. 86:485-486.

Goudet, J. 2001. FSTAT, a program to estimate and test gene diversities and fixation indices (version 2.9.3). 13 Aug. 2015. $<$ http://www2.unil.ch/popgen/softwares/fstat.htm>.

Guo, S.W. and E.A. Thompson. 1992. Performing the exact test of HardyWeinberg proportion for multiple alleles. Biometrics 48:361-372.

Gupta, P.K., H.S. Balyan, P.C. Sharma, and B. Ramesh. 1996. Microsatellites in plants: A new class of molecular markers. Current Sci. (India) 70:45-54.

Gurevitch, J. and D.K. Padilla. 2004. Are invasive species a major cause of extinctions? J. Ecol. 19:470-474.

Hadziabdic, D., X.W. Wang, P.A. Wadl, T.A. Rinehart, B.H. Ownley, and R.N. Trigiano. 2012. Genetic diversity of flowering dogwood in the Great Smoky Mountains National Park. Tree Genet. Genomes 8:855-871.

Hamrick, J.L. and M.J.W. Godt. 1996. Conservation genetics of endemic plant species, p. 281-304. In: J.C. Avise and J.L. Hamrick (eds.). Conservation genetics. Chapman and Hall, New York, NY.

Hamrick, J.L., M.J.W. Godt, and S.L. Sherman-Broyles. 1992. Factors influencing levels of genetic diversity in woody plant species. New For. 6:95-124.

Holsinger, K.E. and L.D. Gottlieb. 1991. Conservation of rare and endangered plants: Principles and prospects, p. 195-223. In: D.A. Falk and K.E. Holsinger (eds.). Genetics and conservation of rare plants. Oxford Univ. Press, Oxford, UK.

Holsinger, K.E. and B.S. Weir. 2009. Genetics in geographically structured populations: Defining, estimating and interpreting FST. Nat. Rev. Genet. 10:639-650.

Homoya, M.A. 1987. A floristic study of a limestone glade in Versailles State Park, Ripley County, Indiana. Proc. Indiana Acad. Sci. 96:407-412.

Hornero, J., F.J. Gallego, I. Martínez, and M. Toribio. 2001. Testing the conservation of Quercus spp. microsatellites in cork oak, $Q$. suber L. Silvae Genet. 50:162-167.

Kati, V., P. Devillers, M. Dufrêne, A. Legakis, D. Vokou, and P. Lebrun. 2004. Testing the value of six taxonomic groups as biodiversity indicators at a local scale. Conserv. Biol. 18:667-675.

Kikuchi, S. and Y. Isagi. 2002. Microsatellite genetic variation in small and isolated populations of Magnolia sieboldii ssp. japonica. Heredity 88:313-321.

Kronholm, I., O. Loudet, and J. deMeaux. 2010. Influence of mutation rate on estimators of genetic differentiation-lessons from Arabidopsis thaliana. BMC Genet. 11:1-14.

Langella, O. 2002. Populations 1.2.31. 13 Aug. 2015. <http://www. bioinformatics.org/ tryphon/populations/>.

Leonard, K.J. 1969. Factors affecting rates of stem rust increase in mixed plantings of susceptible and resistant oat varieties. Phytopathology 59:1845-1850.

Lienert, J. 2004. Habitat fragmentation effects on fitness of plant populations - a review. J. Nat. Conserv. 12:53-72.

Lindenmayer, D.B., C.R. Margules, and D.B. Botkin. 1999. Indicators of biodiversity for ecologically sustainable forest management. Conserv. Biol. 14:941-950.

Mantel, N.A. 1967. The detection of disease clustering and a generalized regression approach. Cancer Res. 27:209-220.

Marra, F.P., T. Caruso, F. Costa, C. Di Vaiio, R. Mafrica, and A. Marchese. 2013. Genetic relationships, structure and parentage simulation among the olive trees (Olea europaea L. subsp. europaea) 
cultivated in southern Italy revealed by SSR markers. Tree Genet. Genomes 9:961-973.

Miliczky, D. and E.A. Osgood. 1979. Insects visiting bloom of the with-rod Viburnumcassanoides L. in the Orono, Maine area. Entomol. News 90:131-134.

National Center for Biotechnology Information. 2013. VecScreen. 13 Aug. 2015. <http://www.ncbi.nlm.nih.gov/tools/vecscreen/>.

Nei, M. 1972. Genetic distance between populations. Am. Nat. 106:283-292.

Newton, A.C., T.R. Allnutt, A.C.M. Gillies, A.J. Lowe, and R.A. Ennos. 1999. Molecular phylogeography, intraspecific variation and the conservation of tree species. Trends Ecol. Evol. 14:140-145.

Nybom, H. 2004. Comparison of different nuclear DNA markers for estimating intraspecific genetic diversity in plants. Mol. Ecol. 13:1143-1155.

Nybom, H. and I.V. Bartish. 2000. Effects of life history traits and sampling strategies on genetic diversity estimates obtained with RAPD markers in plants. Perspect. Plant Ecol. Evol. Syst. 312:93-114.

Page, R.D.M. 1996. TreeView: An application to display phylogenetic trees on personal computers. Comput. Appl. Biosci. 12:357-358.

Peakall, R. and P.E. Smouse. 2006. GENALEX 6: Genetic analysis in Excel. Population genetic software for teaching and research. Mol. Ecol. Notes 6:288-295.

Pritchard, J.K. and P. Donnelly. 2001. Case-control studies of association in structured or admixed populations. Theor. Popul. Biol. 60:227-237.

Pritchard, J.K., M. Stephens, and P. Donnelly. 2000. Inference of population structure using multilocus genotype data. Genetics 155:945-959.
Semaan, M.T. and R.S. Dodd. 2008. Genetic variability and structure of the remnant natural populations of Cedrus libani (Pinaceae) of Lebanon. Tree Genet. Genomes 4:757-766.

Stieneke, D.L. and I.A. Eujayl. 2007. Imperfect SSR Finder 1.0. 13 Aug. 2015. <http://ssr.nwisrl.ars.usda.gov/>.

Till-Bottraud, I. and M. Gaudeul. 2002. Intraspecific genetic diversity in alpine plants. In: C. Körner and E. Spehn (eds.). Mountain biodiversity: A global assessment. Parthenon Publ., London, UK.

Untergrasser, A., I. Cutcutache, T. Koressaar, J. Ye, B.C. Faircloth, M. Remm, and S.G. Rozen. 2012. Primer 3-New capabilities and interfaces. Nucleic Acids Res. 40:e115.

U.S. Department of Agriculture. 2008. The woody plant seed manual. U.S. Dept. Agr., For. Serv. Agr. Hdbk. 727.

Vitousek, P.M. and L.R. Walker. 1989. Biological invasion by Myrica faya in Hawaii: Plant demography, nitrogen fixation, ecosystem effects. Ecol. Monogr. 59:247-265.

Wadl, P.A., A.J. Dattilo, B.E. Scheffler, and R.N. Trigiano. 2011. Development of microsatellite loci for the endangered species Pityopsis ruthii (Asteraceae). Amer. J. Bot. 98:E342-E345.

Wang, X.W., R.N. Trigiano, M.T. Windham, R.E. DeVries, B.E. Scheffler, T.A. Rinehart, and J.M. Spiers. 2007. A simple PCR procedure for discovering microsatellites from small insert libraries. Mol. Ecol. Notes 7:558-561.

Winkworth, R.C. and M.J. Donoghue. 2004. Viburnum phylogeny: Evidence from the duplicated nuclear gene GBSSI. Mol. Phylogenet. Evol. 33:109-126.

Zhang, D.X. and G.M. Hewitt. 2003. Nuclear DNA analyses in genetic studies of populations: Practice, problems and prospects. Mol. Ecol. $12: 563-565$. 